\title{
ASSESSMENT OF GROUND WATER QUALITY DURING DRY SEASON IN JAZAN CITY SOUTHWEST OF SAUDI ARABIA
}

\author{
Hala M. Hassan \\ Chemistry Department, Faculty of Science, Jazan University, Jazan, K.S.A \\ (permanent address) Textile Technology Department, Industrial Education College, \\ Beni-Suef University, Egypt \\ E-mail:hala_mahfooz@yahoo.com
}

\begin{abstract}
This study assesses the quality of ground water from eight different wells in Jazan city southwest of Saudi Arabia. Ground water samples were selected during July 2010 (dry season). Water samples were carefully collected for physico-chemical characteristics. $\mathrm{pH}$, Electrical Conductivity (EC), Total dissolved solids (TDS), $\mathrm{Cl}, \mathrm{SO}_{4}, \mathrm{~F}, \mathrm{NO}_{3}$, $\mathrm{NO}_{2}, \mathrm{SiO}_{3}$, total hardness and turbidity had been analyzed using standard procedures. Selections of important cations which may be toxic in excess when present in drinking water were further discussed $\left(\mathrm{Ca}, \mathrm{Mg}, \mathrm{Na}\right.$ and $\left.\mathrm{NH}_{4}\right)$. The chemical analysis of ground water samples show that not all samples comply with World Health Organization Standards (WHO) for the parameters measured. The bacterial parameters were analyzed for total count of bacteria, E. Coli bacteria and Fecal coliform. It was approved that no bacterial contamination present in the water samples. Results show that not all the water samples are safe for drinking purposes.
\end{abstract}

Keywords: Ground water samples; quality; physico-chemical characteristics; Jazan; Saudi Arabia.

\section{Introduction}

Water is one of the essentials that supports all forms of plant and animal life, [1] it is generally obtained from two principal natural sources; Surface water such as fresh water lakes, rivers, streams, etc. and ground water such as borehole water and well water. [2] In the Kingdom of Saudi Arabia, unlike in many other parts of the world, there are no rivers and the rainfall is very scarce unpredictable, irregular in occurrence which may be very extensive during local storms. Lack of safe drinking water is a major problem in developing countries. Hence the most important source water supply in the country is ground water storage especially in the villages, where the people depend on this source to get their daily needs from wells for domestic and household uses in addition to agricultural purposes. A number of factors influence water chemistry. Gibbs, (1970) proposed that rock weathering, atmospheric precipitation, evaporation and crystallization control the chemistry of water, the influence of geology on chemical water quality is widely recognized. [3] The influence of soils on water quality is very complex and can be ascribed to the processes controlling the exchange of chemicals between the soil and water [4]. The water chemistry of the ground water will mainly consist of inorganic chemicals and suspended solids as a result of urban run-offs [5].

The quality of water may be described according to their physico-chemical and micro-biological characteristics. The quality of ground water is never constant; it is constantly changing in response to daily, seasonal and climatic rhythms. For effective maintenance of water quality through appropriate control measures, continuous monitoring of large number of quality parameters is crucial because the changes in properties of water have far-reaching implications directly to the biota and indirectly to man. [6] Water quality data are thus, essential for the implementation of responsible water quality regulations, for characterizing and remediating contamination and for the protection of the health of humans and ecosystem.

Water has unique chemical properties due to its polarity and hydrogen bonds which means it is able to dissolve, absorb, adsorb or suspend many different compounds, [7] thus, in nature, water is not pure as it acquires contaminants from its surrounding and those arising from humans and animals as well as other biological activities. [8] One of the most important environmental issues today is ground water contamination [9] and between the wide diversity of contaminants affecting water resources, major metals receive particular concern considering their strong toxicity even at low concentrations. [10] They exist in water in colloidal, particulate and dissolved phases [11] with their occurrence in water bodies being either of natural origin (e.g. eroded minerals within sediments, leaching of ore deposits and volcanism extruded products) or of anthropogenic origin (i.e. solid waste disposal, industrial or domestic effluents). [10] Some of the metals are essential to sustain life-calcium, magnesium, potassium and sodium must be present for normal body functions. The present research was 
carried out to determine the physico-chemical parameters and levels of important cations in ground water from Jazan city.
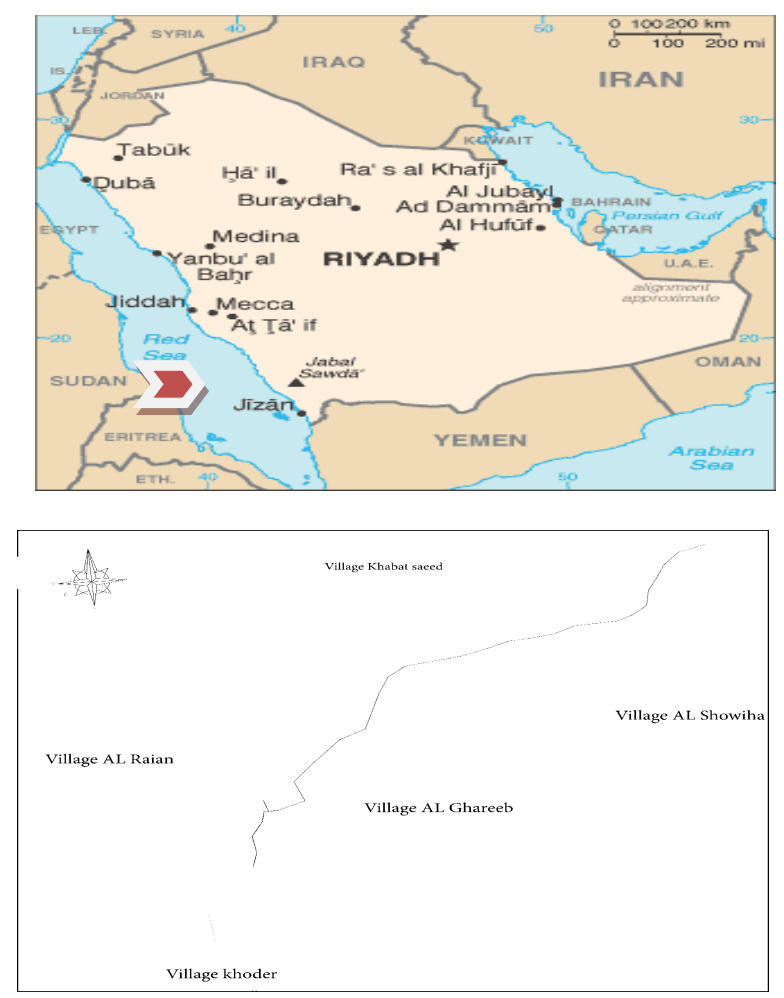

Figure (1): Location map of the study area

\section{Material and Methods}

\section{Sample collection:}

Water wells samples were collected in two times in dry season (July 2010) from eight wells (W-5,W$6, \mathrm{~W}-7, \mathrm{~W}-8, \mathrm{~W}-9, \mathrm{~W}-11, \mathrm{~W}-12$ and $\mathrm{W}-13$ ) in the study area. Before water sampling, all the glass bottles were cleaned and rinsed thoroughly with water to be analyzed. All samples were unfiltered and the concentration of the different parameters could correspond to the total concentration if the ground water was used by the consumers for drinking. The ground water samples were stored at $1-4^{\circ} \mathrm{C}$ temperature prior to analysis in the laboratory.

\section{Physico-Chemical analysis:}

Groundwater samples were analyzed for various chemical parameters as described by the American Public Health Association (APHA, 1995). Figure 1 shows the geographical location of the study area. These parameters include $\mathrm{pH}$, electrical conductivity, total dissolved solids, turbidity and important cations such as calcium, magnesium, ammonia and sodium as well as anions such as carbonates, bicarbonates, chlorides, nitrates, sulfates, silicate and fluorides. The $\mathrm{pH}$ was measured in the field by means of a $\mathrm{pH}$ meter. Electrical conductivity (EC) and total dissolved solids (TDS) were measured in the field by means of digital conductivity meters. Turbidity values were taken using Turbidity meter. Sodium were determined atomic

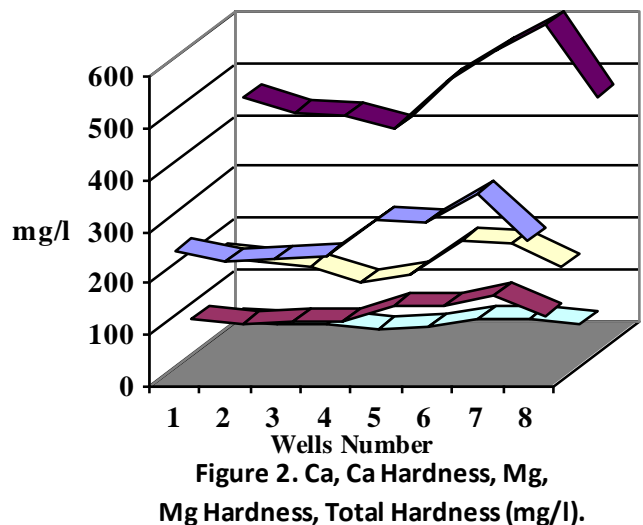

\begin{tabular}{|c|c|c|}
\hline $\begin{array}{l}\square \mathrm{Ca} \text { Hardness } \\
\square \mathrm{Mg}\end{array}$ & $\begin{array}{l}\square \mathrm{Ca} \\
\square \mathrm{T} \text { otal Hardness }\end{array}$ & $\square \mathrm{Mg}$ Hardness \\
\hline
\end{tabular}

absorption spectra (AAS). Total hardness (TH) as $\mathrm{CaCO}_{3}$, calcium $\left(\mathrm{Ca}^{2+}\right)$, magnesium $\left(\mathrm{Mg}^{2+}\right)$, carbonate $\left(\mathrm{CO}_{3}{ }^{2-}\right)$, bicarbonate $\left(\mathrm{HCO}_{3}^{-}\right)$, alkalinity and chloride $\left(\mathrm{Cl}^{-}\right)$were analyzed by volumetric methods. Nitrate $\left(\mathrm{NO}_{3}{ }^{-}\right)$, sulfate $\left(\mathrm{SO}_{4}{ }^{2-}\right)$, silicate $\left(\mathrm{SiO}_{3}{ }^{2-}\right)$, and fluoride $\left(\mathrm{F}^{-}\right.$ ) were determined by colour development and UVVisible spectrometric measurements of absorbance. For total count of bacteria, E. Coli bacteria and Fecal coliform were determined using (APHA) methods. Some statistical analysis are done using excel program.

\section{Results and Discussions:}

Ground water may contain some natural impurities or contaminants, even with no human activity or pollution. Natural contaminants can come from many conditions in the watershed or in the ground. Water moving through underground rocks and soils may pick up magnesium, calcium and chlorides. Some ground water naturally contains dissolved elements such as arsenic, boron, selenium, or radon, a gas formed by the natural breakdown of radioactive uranium in soil.

The results of the chemical analysis of ground water from this area are presented in the following Tables and Figures. So, it is necessary to make a comparison of ground water quality of the study areas with some drinking water standards.

\section{Total Hardness}

Figure 2: Show the $\mathrm{Ca}$ concentrations, $\mathrm{Mg}$ concentrations and total hardness of the wells water. In ground water, hardness is primarily due to the presence of carbonate, bicarbonate, sulphates and chloride of calcium and magnesium. The SAS (1993) states that the optimum value for the

maximum allowable value of $\mathrm{Mg}$ concentrations, $\mathrm{Ca}$ concentrations and total hardness are 150, 200 and 500 $\mathrm{mg} / \mathrm{l}$ respectively. Using this standards some of the wells water samples not suitable for drinking. The highest value is obtained at two sites (W-11 and W-12) with the value 550 and $600 \mathrm{mg} / \mathrm{l}$.

The total hardness was high in the ground water in some areas. This water stagnant might water was not 
being used regularly, this have led to the accumulation of salts in the well.

The observed result of TDS, Table (3) also correlates to the hardness result. Overall, these results show a direct relationship between chloride concentration, hardness, conductivity and TDS.

Anions:

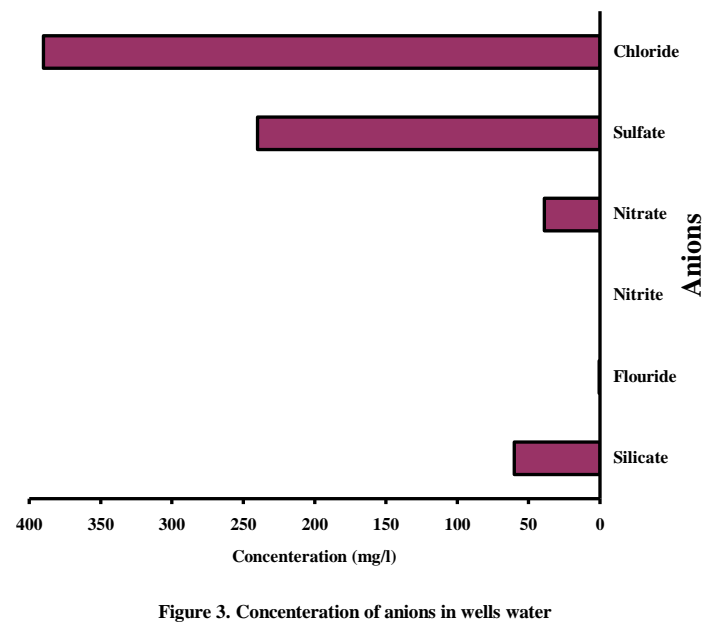

Figure 3: Give average values of the results obtained in this study for concentrations of anions in the wells water. The concentration level ranged from $0.033 \mathrm{mg} / \mathrm{l}$ to $390.5 \mathrm{mg} / \mathrm{l}$. The SAS (1984) states that the optimum value for the maximum allowable value is $600 \mathrm{mg} / 1$. The order of the relative abundance of major anion in the ground water was $\mathrm{Cl}^{-}>\mathrm{SO}_{4}{ }^{2-}>\mathrm{SiO}_{3}{ }^{2-}>\mathrm{NO}_{3}{ }^{-}>\mathrm{F}^{-}$ $>\mathrm{NO}_{2}^{-}$, with $\mathrm{Cl}^{-}$the dominant anion.

The chloride $\left(\mathrm{Cl}^{-}\right)$concentration values ranged from 68 $\mathrm{mg} / \mathrm{l}$ to $630 \mathrm{mg} / \mathrm{l}$. The SAS states that the optimum value of the concentration of chloride for drinking water is $200 \mathrm{mg} / \mathrm{l}$ and the maximum allowable value is $600 \mathrm{mg} / \mathrm{l}$. Using this standard, the water samples of all locations were within the maximum allowable value of the chloride. The USEPA (1994) states that the maximum allowable value of chloride is $250 \mathrm{mg} / \mathrm{l}$. Using the American standard, the water sample were found to be exceeding the permissible limit for chloride. The presence of chloride in higher amounts may be due to natural processes such as the passage of water through natural salt formations in the earth. $\boldsymbol{p H}$

In Table (3) the $\mathrm{pH}$ of wells water was within the Saudi Arabian Specification Standards (SAS) that requires the $\mathrm{pH}$ range to be $7.0-8.5$. All the $\mathrm{pH}$ values were within the United Stated Environmental Protection Agency (USEPA 1994) the $\mathrm{pH}$ to be in the range of 6.5-8.5 drinking water.

\section{Total Dissolved Solids}

The total dissolved solids (TDS) of the water samples ranged from $967 \mathrm{mg} / \mathrm{l}$ to $1476 \mathrm{mg} / \mathrm{l}$, Table (3). The Saudi Arabian Specification and Measurements Agency states that the optimum value for the (TDS) is $500 \mathrm{mg} / \mathrm{l}$, and the maximum allowable value is 1500 $\mathrm{mg} / \mathrm{l}$. Using this standard, all the samples are within the maximum allowable value of the total dissolved solids. The (TDS) in some wells exceeded the maximum allowable value in the USEPA limits (W-11 and W12), which make their drinking use impossible before remove the exceeding total dissolved solids or dilution with water of low total dissolved solids. From the total dissolved solids examination, it was obvious that the total dissolved solids differ from one location to another and from well to well. This is an indication of the difference of the types of soil and rock that the ground water passes through.

According to a salinity classification by (USSLS (1954), [12] the percentages of water samples quality are $25 \%$ of samples are non-saline and $75 \%$ are slightly- saline. Table (1)

Table (1): Classification of the water samples on the basis of TDS

\begin{tabular}{c|c}
$\begin{array}{c}\text { Classification of } \\
\text { ground water }\end{array}$ & $\begin{array}{c}\text { Total dissolved } \\
\text { solid }(\mathbf{m g} / \mathbf{l})\end{array}$ \\
\hline Non-saline & $<1000$ \\
\hline Slightly saline & $1,000-3,000$ \\
\hline Moderately saline & $3,000-10,000$ \\
\hline Very saline & $10,000-35,000$ \\
\hline Brine & $>35,000$
\end{tabular}

\section{Source: Davis and De Wiest, (1996) [13] \\ Electric Conductivity}

Direct measurement of electric conductivity is potentially a very sensitive procedure for measuring ionic concentrations, since conductivity depends on ionic concentration, their mobility etc. Conductivity is not a problem in itself and just because it is above certain level does not mean that the water will cause illness. [14] The average value for the electric conductivity (EC) was 1552 micro-mohs and it was ranging from 1452 micro-mohs to 1882 micro-mohs, Table (3) Saudi Arabian Specifications and Measurements Agency states that the optimum value for the electric conductivity is 800 , and the maximum allowable value is 2300 micro-mohs. Using this standard, all of the wells were within the optimum value. The WHO standards recommendation for the EC is only 1400 micro-mohs, so the EC in some wells exceeded the maximum allowable value in the WHO limits. Electrical conductivity is a decisive parameter in determining suitability of water according to electrical conductivity as follows Table (2):

Table (2): Classification of the water samples on the basis of electrical conductivity

\begin{tabular}{|c|c|}
\hline $\begin{array}{c}\text { Classification of } \\
\text { ground water }\end{array}$ & \begin{tabular}{c} 
EC in \begin{tabular}{c|}
$\boldsymbol{\mu m h o s} / \mathbf{c m}$ at \\
$\mathbf{2 5}^{\circ} \mathbf{C}$
\end{tabular} \\
\hline Excellent
\end{tabular} \\
\hline Good & $250-750$ \\
\hline Permissible & $750-2000$ \\
\hline Doubtful & $2000-3000$ \\
\hline Unsuitable & $>3000$ \\
\hline
\end{tabular}


Source: Todd, (1980) [15]

Turbidity

Turbidity is an important parameter for characterizing the quality of water. Turbidity may be caused when light is blocked by large amounts of silt, microorganisms, plant fibers, sawdust, wood ashes, chemicals and coal dust. The water samples having turbidity $0.6 \mathrm{NTU}$, Table (3) which is within the desirable limit of 5 NTU.

\section{Sodium}

The SAS (1997) and USEPA state that the maximum allowable value of sodium $\left(\mathrm{Na}^{+}\right)$is 200 $\mathrm{mg} / \mathrm{l}$. Sodium was found to be $140 \mathrm{mg} / \mathrm{l}$, using this standards, this value was within the maximum allowable value of the sodium. Overall the distribution of $\mathrm{Na}$ did not pose any significant water quality problem, it was within the standard acceptable levels of drinking water determined by WHO.

\section{Ammonia}

The term ammonia includes the non-ionized $\left(\mathrm{NH}_{3}\right)$ and ionized $\left(\mathrm{NH}_{4}{ }^{+}\right)$species. Ammonia in the environment originates from metabolic, agricultural and industrial processes and from disinfection with chloramine. Natural levels in ground water and surface water are usually below $0.2 \mathrm{mg} / 1$ (WHO).

According to (Atxotegi et al, 2003), [16] ammonium ion $\left(\mathrm{NH}_{4}\right)$ is transformed into ammonia $\left(\mathrm{NH}_{3}\right)$ based on $\mathrm{pH}$ through the following reaction:

$\mathrm{NH}_{4}{ }^{+} \rightarrow \mathrm{NH}_{3}+\mathrm{H}^{+}$or

$\mathrm{NH}_{4} \mathrm{OH} \rightarrow \mathrm{NH}_{3}+\mathrm{H}_{2} \mathrm{O}$

The obtained values of ammonia are within the desirable limit, Table (3).

\section{Total Alkalinity}

Alkalinity is an important parameter because it measures the water's ability to resist acidification. The constituents of alkalinity in neutral system include mainly carbonate, bicarbonate, hydroxide and other components which may contribute to alkalinity are $\mathrm{H}_{2} \mathrm{BO}_{3}{ }^{2-}, \mathrm{HPO}_{4}{ }^{2-}$ and $\mathrm{HS}^{-}$. The SAS states that the maximum allowable value of the total alkalinity for drinking water is $400 \mathrm{mg} / \mathrm{l}$, Table (3). The WHO standard desirable limit of alkalinity in potable water is $120 \mathrm{mg} / \mathrm{l}$. The value of the water samples for total alkalinity was within the limit.

Table 3: Some physico-chemical properties of ground water

\begin{tabular}{|c|c|}
\hline Chemical Parameters & Mean \pm S.D. \\
\hline $\mathrm{pH}-$ value $\left(25^{\circ} \mathrm{C}\right)$ & $7 \pm 0.0001$ \\
\hline $\begin{array}{c}\text { Total dissolved solid } \\
\text { salts }(\mathrm{mg} / \mathrm{l})\end{array}$ & $1476 \pm 0.0003$ \\
\hline Total alkalinity $(\mathrm{mg} / \mathrm{l})$ & $20.5 \pm 0.0002$ \\
\hline Ammonia $(\mathrm{mg} / \mathrm{l})$ & $0.03 \pm 0.00012$ \\
\hline
\end{tabular}

\begin{tabular}{|c|c|}
\hline Conductivity $\left(25^{\circ} \mathrm{C}\right)$ & $1555 \pm 0.0004$ \\
\hline $\begin{array}{c}\text { Turbidity (NTU, } \\
\text { nephelometrc turbidity } \\
\text { unit) }\end{array}$ & $0.6 \pm 0.0001$ \\
\hline
\end{tabular}

Sample have been analyzed using SPSS program, at significant $(P<0.01)$.

Water is a medium of thousands of microorganisms some of which are disease causing. Diseases in humans can be caused by the presence of certain pathogenic bacteria and other organisms such as viruses, protozoa and worms. Pathogens, causing diarrhoea-related illness such as cholera, are commonly derived from human faecal material. Globally, 4 billion cases of diarrhoea are reported every year causing 1.8 million deaths, out of which about $90 \%$ are children under five (UNESCO, 2007).[17] Pathogens can readily be washed into water bodies such as shallow wells. Without treatment, such water is a major cause of illness if consumed and may result in loss of productivity and increased medical costs Potable water is defined as water that is free from pathogens, low in compounds that are acutely toxic or that have grave long-term effects on human health.[18] Potable water should also be free from compounds that can cause colour, taste (high salinity) and odour. Shallow wells are normally located in the valleys where the ground water table is relatively high $(1-4 \mathrm{~m}$ below ground level) and infiltration of rain and river water plays a main part in ground water recharge.

The standard bacteriological test screens for coliform bacteria. These bacteria do not necessarily cause disease themselves, but their presence indicates contamination and the possible presence of disease-causing organisms such as pathogenic bacteria, viruses, or intestinal parasites. The presence of coliform bacteria means contamination from surface water sources, as these are not found in ground water. The private wells must be tested for coliform bacteria every one to two years. This is especially important if the well is shallow, old, or of substandard construction. Frequent testing is also recommended if it is located close to a source of human or animal waste, such as a septic tank drainfield, barnyard, or animal feeding operation.

Table 4. Shows bacteriological parameters of wells water samples, all the wells water samples were suitable. It approved that no bacterial contamination is presented (E. coli bacteria, Fecal coliform and total count of bacteria).

Table 4: Bacteriological parameters of wells water samples

\begin{tabular}{|c|c|}
\hline $\begin{array}{c}\text { Bacteriological } \\
\text { parameters }\end{array}$ & Mean \pm S.D. \\
\hline Total count of bacteria & 18 \\
\hline E.coli bacteria & $-\mathrm{ve}$ \\
\hline Fecal coliform & $-\mathrm{ve}$ \\
\hline
\end{tabular}

\section{Conclusion:}


Drinking water can be obtained from a number of sources, the one used often depending on the relative availability of surface water (such as rivers, lakes, and reservoirs) and ground water aquifers. In Jazan Southwest Saudi ground water from tube-wells is an important source of drinking water. Ground water as the source of drinking water is usually preferred because of its good naturally stable state of microbial quality. However, in some cases ground water may contain chemical constituents hazardous to the health. this research give the summary of the results obtained in this study for concentrations of anions in the wells water. The concentration level ranged from $0.033 \mathrm{mg} / \mathrm{l}$ to $390.5 \mathrm{mg} / 1$. The chemical parameters of the wells water also studied. The $\mathrm{pH}$ of wells water was 7.0-8.5. The total dissolved solids of the water samples ranged from $967 \mathrm{mg} / \mathrm{l}$ to $1476 \mathrm{mg} / \mathrm{l}$. The electric conductivity values of the wells water samples ranged from 1452 micro-mohs to 1882 micro-mohs. All the wells water samples were suitable. It proved that no bacterial contamination is presented (E. coli bacteria, Fecal coliform and total count of bacteria. Most the ground water samples collected were having the concentrations of many parameters within the permissible limit. The quality of ground water is acceptable in almost all the samples.

\section{References:}

[1] Vanloon GW and Duffy SJ. (2005). The Hydrosphere. In: Environmental Chemistry: A Global Perspective.2nd Edn. New York: Oxford University Press;197-211.

[2] McMurry J and Fay RC. (2004). Hydrogen, Oxygen and Water. In: McMurry Fay Chemistry. K.P. Hamann, (Ed.).4th Edn. New Jersey: Pearson Education: 575-599.

[3] Gibbs, R. J. (1970). Mechanisms controlling world water chemistry. Science 170: 1088-1090.

[4] Hesterberg, D. (1998). Biogeochemical cycles and processes leading to changes in mobility of chemicals in soils. Agric. Ecosystem Environ. 67: 121-133

[5] McGregor, D.F.M., Thompson, D.A. and Simon, D. (2000). Water quality and \# management in peri-urban Kumasi, Ghana'. Case Study 16 inlandWater Linkages in Rural Watersheds. FAO electronic workshop, FAO, Rome

[6] Kara, C., \& Comlekci, U. (2004).Journal of KSU 7:1.

[7] World Health Organization WHO. (2007). Water for Pharmaceutical Use. In: Quality Assurance of Pharmaceuticals: A Compendium of Guidelines and Related Materials. 2nd Updated Edn. World Health Organisation, Geneva: (2): 170-187.

[8] Mendie U. (2005). The Nature of Water. In: The Theory and Practice of Clean Water Production for Domestic and Industrial Use. Lagos:Lacto-Medals Publishers:1-21.
[9] Vodela JK, Renden JA, Lenz SD, Mchel Henney WH and Kemppainen BW. Drinking water contaminants. Poult. Sci., 1997;(76):1474-1492.

[10] Marcovecchio JE, Botte SE and Freije RH. Heavy Metals, Major Metals, Trace Elements. In: Handbook of Water Analysis. L.M. Nollet, (Ed.) (2007). $2^{\text {nd }}$ Edn. London: CRC Press: 275-311.

[11] Adepoju-Bello AA, Ojomolade OO, Ayoola GA and Coker HAB. (2009). Quantitative analysis of some toxic metals in domestic water obtained from Lagos metropolis. The Nig. J. Pharm.: 42(1): 5760.

[12] USSLS (United States Salinity Laboratory Staff): (1954). Diagnosis and improvement of saline and alkaline soils. US Deptt. Agriculture, Handbook 60. pp. 160

[13] Davis, S.N., and De Wiest (1996): "Hydrogeology", John Wiley \& Sons, New York, P. 463.

[14] David C. (2004). Small Water Supplies. India: Cromwell Press.

[15] Todd D, (1980). "Ground water hydrology", 2nd edn. Wiley, New York, $535 \mathrm{pp}$.

[16] Atxotegi A, Iqbal MZ and Czarnetzki AC. (2003). A preliminary assessment of nitrate degradation in simulated soil environments. Environ. Geol:(45)161-170. DOI: 10.1007/s00254-0030876-0

[17]UNESCO. UNESCO Water Portal newsletter (2007). No. 161: Water - related Diseases.

[18] Shultz CR, Okun DA. (1984). Surface water treatment for communities in developing countries. John Wiley \& Sons, Inc., Intermediate Technology Publications, Great Britain. 